\title{
RANCANG BANGUN SISTEM INFORMASI PENGGOLONGAN PERAN PADA SISTEM PEMBELAJARAN UNIVERSITAS MENGGUNAKAN MEDIA SOSIAL
}

\author{
Arief Andriono, S.T ${ }^{1}$, Eko Nur Hermansyah, S.Hum ${ }^{2}$, Firdaus Dwi Prasetyo, S.Kom ${ }^{3}$, N. \\ A. Miftahul Huda, SST ${ }^{4}$, Trisna Wonda, S.Kom ${ }^{5}$, Prof. Dr. Ir. Eko Sediyono, M.Kom ${ }^{6}$, \\ Dr. Anwar S. Ardjo ${ }^{7}$ \\ 1,2,3,4,5,6,7 Program Studi Magister Sistem Informatisi, Fakultas Teknologi Informasi, \\ Universitas Kristen Satya Wacana, \\ Jln. Diponegoro No. 52-60, Salatiga, 50711, Indonesia \\ E-mail:.1 arief527ffa00@gmail.com, ${ }^{2}$ ekonurhermansyah@gmail.com, ${ }^{3}$ \\ castlevania713@gmail.com, ${ }^{4}$ mift.huda@hotmail.com, ${ }^{5}$ iznacr05@gmail.com, \\ 6ekosed1@yahoo.com, ${ }^{7}$ anwars.ardjo@gmail.com
}

\begin{abstract}
Abstrak
Penelitian ini dilakukan untuk mendapatkan rancangan sistem informasi yang diharapkan dapat digunakan untuk menggolongkan masing-masing peran guna mempermudah pengguna untuk mendapatkan informasi secara spesifik sesuai dengan subyek yang dibutuhkan. Penelitian ini dilakukan di Fakultas Teknologi Informasi UKSW, dalam pelaksanaannya penelitian ini menggunakan pendekatan kualitatif deskriptif. Analisis dan desain dalam penelitian ini menggunakan metode Object Oriented Analisis Design. Media sosial e-learning dapat menyediakan ruang diskusi pembelajaran bagi pengguna yang sedang membutuhkan informasi, di dalam ruang diskusi terdapat lecture yang memberikan referensi tentang kebutuhan refrensi dari pengguna. Media sosial menyediakan penggolongan peran pada aktor pengguna sesuai bidang yang dikuasai oleh pengguna, sehingga pengguna lain dapat memperoleh referensi dan informasi yang sesuai dengan bidang yang dibutuhkan. Manfaat media sosial ini dapat memberikan referensi dan informasi yang sesuai dengan kebutuhannya, serta dapat memperoleh pembelajaran yang sesuai dengan kebutuhan informasi dari pengguna.
\end{abstract}

Kata kunci-Media Sosial, E-Leaning, Penggolongan Peran, OOAD, Lecture

\begin{abstract}
This study was conducted to obtain information system design which is expected can be used to categorize each user's role in order to facilitate the users to get specific information in accordance with the required subjects. This study was conducted at the Faculty of Information Technology SWCU using descriptive qualitative approach on it's implementation and using Object Oriented Analysis Design on it's Analysis and Design. E-learning social media provides learning discussion room for users who need the information. Inside the discussions room, there are lectures that gives references needed by user. Social media provides role categorization based on the field which was fully understood by the user, so that the other users can obtain references and information in accordance with the required fields. The benefits of this social media are, it can provide a references and information based on needs and provide learning in accordance with the information needed by user.
\end{abstract}

Keywords - Social Media, E-Learning, Role categorization, OOAD, Lecture 


\section{PENDAHULUAN}

Media sosial merupakan salah satu perkembangan dari teknologi internet berbasis WEB, yang memudahkan semua orang untuk berkomunikasi secara online dan membentuk jaringan sendiri sehingga dapat memudahkan dalam penyebarluasan konten mereka. Media sosial secara umum memiliki fitur yang dapat digunakan pengguna untuk menampilkan data mengenai profil pengguna kepada pengguna lain. Menurut Setyani (2013) fitur lain yang juga tersedia dalam media sosial berupa fitur yang untuk dapat membaharui (update) status, unggah data dan pengolahan pesan dalam situs[1]. Kesuksesan dalam memberikan informasi dari media sosial masih dirasa belum maksimal dikarenakan kurangnya cara untuk mendapatkan informasi secara spesifik mengenai suatu subyek menjadi salah satu masalah dalam pembelajaran, sehingga membutuhkan suatu sistem informasi pembelajaran yang dapat melakukan penggolongan peran dari penyedia informasi yang menguasai suatu subjek tersebut dan menjadi tempat mencari referensi yang sesuai dengan bidang yang dibutuhkannya. Berdasarkan uraian di atas untuk mendapatkan informasi secara spesifik mengenai suatu subyek, maka dibuat "Rancang bangun sistem informasi penggolongan peran pada sistem pembelajaran universitas menggunakan media sosial". Sistem informasi yang akan dibangun diharapkan dapat digunakan untuk menggolongkan masing-masing peran dari user guna mempermudah pengguna untuk mendapatkan informasi secara spesifik sesuai dengan subyek yang dibutuhkan.

\section{KAJIAN TEORI}

\section{$2.1 O O A D$}

Hasil analisis berorientasi objek adalah deskripsi dari apa sistem secara fungsional diperlukan untuk melakukan, dalam bentuk sebuah model konseptual. Menurut Ependi (2014), OOD mengubah model konseptual yang dihasilkan dalam analisis berorientasi objek memperhitungkan kendala yang dipaksakan oleh arsitektur yang dipilih dan setiap nonfungsional teknologi atau lingkungan kendala, seperti transaksi throughput, response time, run waktu platform, lingkungan pengembangan, atau bahasa pemrograman[2].

\section{$2.2 U M L$}

Unified Modelling Language (UML) adalah sebuah "bahasa" yang telah menjadi standar dalam industri untuk visualisasi, merancang dan mendokumentasikan sistem piranti lunak. UML menawarkan sebuah standar untuk merancang model sebuah sistem. UML dapat membuat model untuk semua jenis aplikasi piranti lunak, dimana aplikasi tersebut dapat berjalan pada piranti keras, sistem operasi dan jaringan apapun, serta ditulis dalam bahasa pemrograman apapun. Tetapi karena UML juga menggunakan class dan operation dalam konsep dasarnya, maka ia lebih cocok untuk penulisan piranti lunak dalam Bahasa bahasa berorientasi objek seperti $\mathrm{C}++$, Java, C\# atau VB.NET. Walaupun demikian, UML tetap dapat digunakan untuk memodelkan aplikasi prosedural dalam VB atau C[3].

\subsection{Penelitian Terdahulu}

Penelitian pertama berjudul, "E-Learning sebagai Media Pembelajaran Interaktif Berbasis Teknologi Informasi" oleh Yazdi pada tahun 2012 di SMK 1 Tolitoli. Hasil dari penelitian ini adalah prototype modul e-learning yang dikembangkan sesuai dengan pengembangan sistem yang ada terbagi dua, yaitu: konten guru dan konten siswa. Konten guru mempunyai aksesibilitas luas, seperti: membuat soal, membuat pengumuman akademik, meng-upload materi pelajaran, memeriksa dan mengumumkan hasi ujian. Sedangkan konten siswa, hanya terbatas pada akses melihat saja (pengumuman akademik, hasil ujian), mengikuti ujian, men- 
download materi pelajaran dan tugas, selain itu ada aktivitas interaktif antara guru dan siswa, yaitu : chatting, diskusi/forum[4].

Persamaan penelitian Yazdi dengan penulis adalah sama-sama membuat media pembelajaran (e-learning). Perbedaannya metode yang digunakan di penelitian sebelumnya menggunakan metode dengan menganalisis dan memodifikasi sistem yang sudah ada pada sistem pembelajaran PAI (Pendidikan Agama Islam) di SMK 1 Tolitoli sedangkan metode yang digunakan oleh penulis adalah metode OOAD.

Penelitian kedua berjudul, "Analisis dan Perancangan Perangkat Lunak Media Sosial untuk Berbagi Informasi Diskon" oleh Alkaff. Hasil dari penelitian ini menunjukkan sebuah media sosial untuk berbagi informasi diskon mempunyai 2 aktor untuk memenuhi kebutuhannya, yaitu administrator dan pengguna. Administrator memiliki fungsi untuk mengelola data kategori produk, untuk pengguna, media sosial berbagi diskon harus menyediakan fitur sebagai berikut, memasukkan informasi diskon, menampilkan informasi diskon berdasarkan lokasi dan konteks, penentuan filter informasi diskon berdasarkan konteks dilakukan untuk mengatasi adanya informasi diskon yang berlebih yang mungkin tidak diperlukan oleh pengguna, pencarian informasi diskon dan pengguna, menampilkan profil pengguna [5]. Persamaan penelitian kedua dengan penulis adalah sama-sama membuat media sosial.

\section{METODOLOGI PENELITIAN}

Penelitian ini dilakukan di Fakultas Teknologi Informasi UKSW, dalam pelaksanaannya penelitian ini menggunakan pendekatan kualitatif deskriptif. Analisis dan desain dalam penelitian ini menggunakan metode Object Oriented Analisis Design. Populasi yang akan digunakan sebagai penelitian adalah mahasiswa UKSW Salatiga. Pengambilan sampel pada penelitian ini menggunakan Accidental Sampling, sampel diambil secara kebetulan. Meninjau tempat peristiwa yang diteliti dan mewawancarai orang-orang yang kebetulan berada dan melihat peristiwa tersebut. Peneliti datang ke UKSW dan melakukan wawancara kepada pengguna yang saat itu kebetulan ada.

\subsection{Requirement Engineering}

Kuesioner digunakan untuk memperoleh data tentang kebutuhan sistem mengenai penggunaan media sosial oleh pengguna dan narasumber.

\section{Pengguna}

1. Apakah anda sering mencari referensi tugas melalui media sosial?

2. Portal mana saja yang sering anda gunakan untuk mencari referensi?

3. Apakah media sosial yang anda gunakan sudah membantu anda dalam mencari referensi?

4. Bentuk referensi seperti apa yang sering anda cari untuk memenuhi kebutuhan informasi anda?

5. Referensi dengan syarat seperti apa yang menjadi patokan anda dalam mencari informasi?

6. Kata kunci apa yang sering anda tuliskan untuk mencari referensi?

7. Apakah dalam mencari referensi anda sering melihat terlebih dahulu sumbernya?

8. Apakah referensi dari media sosial sesuai dengan kebutuhan tugas anda?

9. Apakah narasumber dari media sosial membantu anda dalam mencari referensi tugas?

10. Fitur apa yang anda sering gunakan dalam media sosial? 
Narasumber

1. Apakah media sosial yang anda gunakan sudah memberi anda ruang untuk menyebarkan informasi?

2. Apakah media sosial yang anda gunakan sudah memberikan penggolongan peran sebagai narasumber sesuai dengan bidang yang anda kuasai?

3. Seberapa sering anda membagi informasi melalui media sosial?

4. Apakah anda mengetahui seberapa sering karya anda digunakan sebagai referensi?

5. $\quad$ Fitur apa yang anda sering gunakan dalam media sosial?

\subsection{Requirements Specification}

Bagian ini mendefinisikan interface yang harus didukung oleh aplikasi. Sistem ini harus berisi spesifikasi yang memadai, protokol, port dan alamat logis, dll, sehingga perangkat lunak dapat dikembangkan dan diverifikasi terhadap persyaratan antarmuka.

Tahapan ini digunakan untuk menetapkan perilaku sistem, batasan-batasan dalam impelementasinya, serta memuat gambaran sistem. Requirement dalam penelitian ini adalah :

- $\quad$ Sistem harus menyediakan fasilitas ruang untuk menyebarkan informasi (referensi).

- $\quad$ Sistem harus menyediakan fasilitas ruang untuk komunikasi antar pengguna.

- Sistem harus menyediakan penggolongan narasumber sesuai dengan bidangnya.

- Sistem harus menyediakan ruang agar pengguna dapat berkomunikasi dengan narasumber.

- $\quad$ Sistem harus mempunyai petunjuk untuk mendapatkan referensi dari media sosial.

\section{Batasan Sistem}

- $\quad$ Sistem media sosial ini ditujukan untuk mahasiswa dan dosen.

- $\quad$ Sistem ini dikelola oleh administrator.

- $\quad$ Ruang yang terdapat dalam sistem dibagi berdasarkan bidang ilmu yang telah ditentukan.

- $\quad$ Narasumber memiliki profil yang menampilkan bidang ilmu yang dikuasainya.

- $\quad$ Referensi yang disediakan berdasarkan kategori yang ditentukan.

- $\quad$ Bentuk referensi yang disediakan: jurnal ilmiah, proceeding, whitepaper, index dan ebook.

- Media sosial ini hanya dapat diakses oleh pengguna yang terdaftar di dalam komunitas universitas.

- Hanya mahasiswa UKSW yang dapat mengakses sistem.

- Narasumber dari luar universitas dapat membagikan informasi, dengan login sebagai tamu.

\subsection{Validation}

Setelah requirements specification berhasil dibuat, perlu dilakukan dua usaha: Validation (validasi), yaitu proses untuk memastikan bahwa requirements yang benar sudah ditulis. Verification (verifikasi), yaitu proses untuk memastikan bahwa requirements sudah ditulis dengan benar. Proses validasi dan verifikasi ini melibatkan customer (user) sebagai pihak yang menilai dan memberi feedback berhubungan dengan requirements.

\section{HASIL DAN PEMBAHASAN}

Pada bab ini dibahas hasil penelitian setelah dilakukan wawancara, dan studi pustaka, kemudian dilakukan analisis data dengan metode OOAD dan membuat rancangan sistem informasi sesuai dengan metode OOAD. 
Hasil dari wawancara yang dilakukan kepada mahasiswa uksw FTI digunakan untuk pengembangan sistem informasi yang dibutuhkan oleh $u$ ser.

Sistem informasi digunakan untuk penggolongan peran dilakukan untuk memudahkan pembagian peran sesuai dengan kebutuhan dari masing-masing user ketika mencari sumber informasi dari media sosial e-learning. Sistem ini menyediakan penggolongan peran yang sesuai dengan bidang yang dikuasai oleh user, dan ketika user menguasai bidang tertentu user tersebut dapat menjadi narasumber pada grup yang sesuai dengan grup pembahasan yang dikuasainya, didalam grup ini dapat melakukan chating dengan semua user yang bergabung dalam grup untuk mendiskusikan topik yang sesuai dan narasumber yang ada didalamnya dapat menyediakan refrensi yang sesuai. Media sosial ini menyediakan repository untuk menampung semua sumber referensi yang dapat digunakan user untuk memenuhi kebutuhan informasinya.

UML yang merupakan standar dari pemodelan sistem informasi digunakan untuk membuat model dari sistem informasi yang dibangun pada penelitian ini.

\subsection{Perancangan Use Case Diagram}

\subsubsection{Penentuan aktor}

Penentuan aktor pada sistem media sosial untuk mencari sumber referensi, aktor dibedakan menjadi admin dan pengguna. Wewenang dari masing-masing aktor tersebut adalah sebagai berikut:

\subsubsection{Admin}

Admin merupakan aktor yang menempati tingkatan tertinggi pada sistem. Admin memiliki wewenang yaitu :

1. Memasukkan data pengguna media sosial

2. Melakukan perubahan data pada media sosial

3. Melakukan penghapusan data pada media sosial

4. Melakukan penggolongan pengguna pada media sosial

\subsubsection{Pengguna}

Pengguna mempunyai tingakatan wewenang di bawah admin, pengguna mempunyai wewenang sebagai berikut :

1. Membuat grup diskusi

2. Bergabung pada grup diskusi yang ada

3. Membuat private chat

4. Mengupload materi referensi

5. Mendowload materi referensi

6. Meninggalkan grup diskusi

7. Mengikuti test

8. Melakukan penilaian

\subsubsection{Perancangan}

Perancangannya adalah sebagai berikut:

\subsubsection{Use Case Media sosial}

Use case media sosial dibuat sesuai dengan analisis data yang diperoleh saat wawancara. Penggolongan peran user dilakukan oleh admin, sesuai dengan data yang diperoleh dari pengguna tersebut. Dengan adanya penggolongan peran diharapkan pengguna dapat memperoleh informasi yang tepat sesuai dengan kebutuhan, dan narasumber dapat memberi informasi atau referensi sesuai dengan bidang yang dikuasai. 


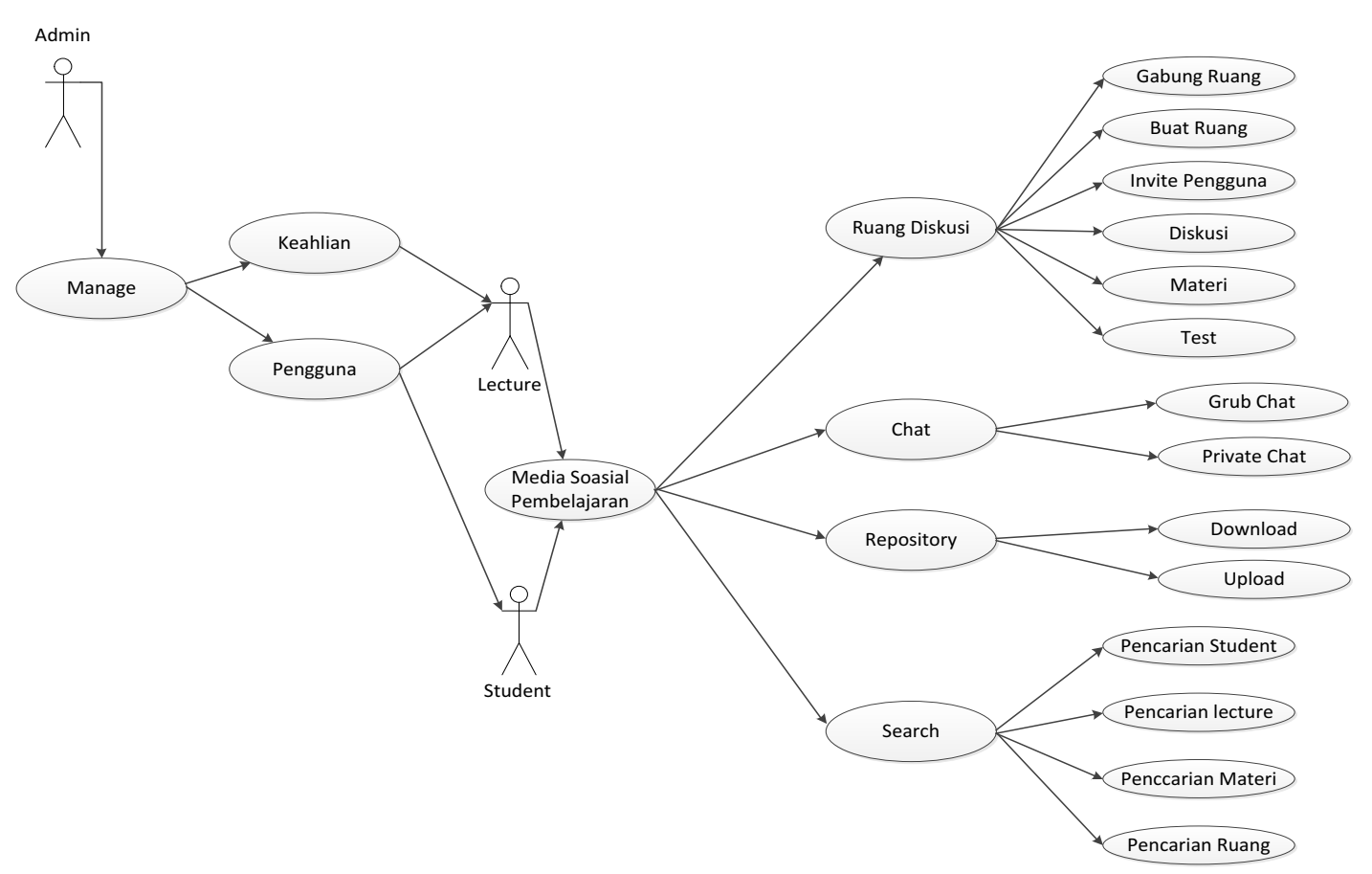

Gambar 1 Use Case Media Sosial

\subsubsection{Desain Interface yang Ditawarkan}

Sistem media sosial e-learning ini dibuat sesuai dengan data yang diperoleh saat wawancara dengan menganalisisnya dan membuat sistem sesuai dengan sistem perancangan OOAD dengan pemrograman PHP.

Gambar 2 menjelaskan tentang login untuk pengguna aplikasi untuk autentifikasi user.

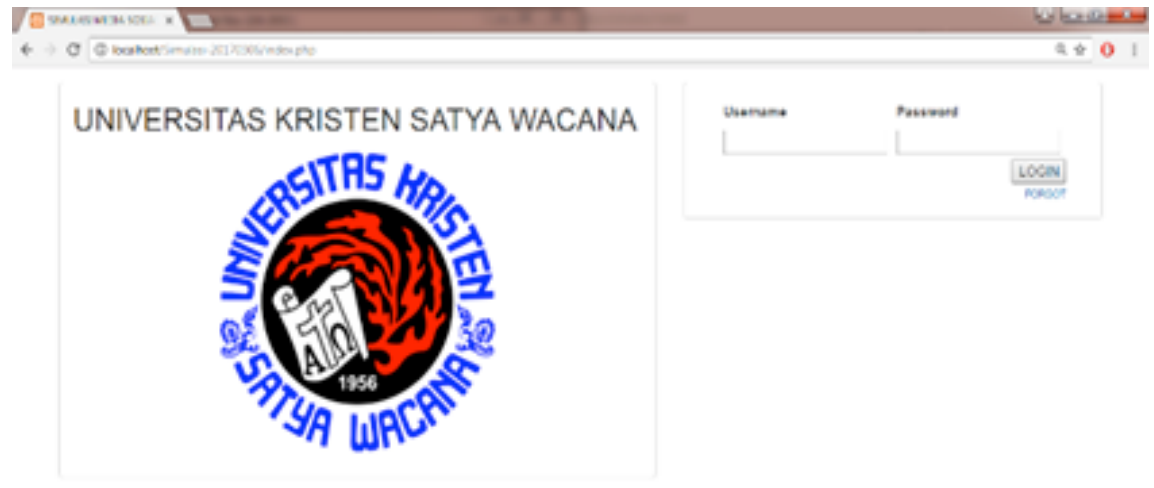

\section{Gambar 2 Tampilan Login Pengguna Aplikasi}

Gambar 3 menjelaskan halaman muka sebagai admin, dalam aplikasi ini admin memiliki peran sebagai manajemen user dimana admin dapat melakukan tambah user, edit user dan hapus user. Halaman admin menunjukkan semua user yang sudah terdaftar pada aplikasi. Manajemen keahlian user diatur oleh admin seperti pada gambar 4. Request dari user untuk menambahkan keahlian akan ditujukan kepada admin untuk ditambahkan pada aplikasi. 
Computatio: Journal of Computer Science and Information Systems, volume 1, no 2, Oktober 2017

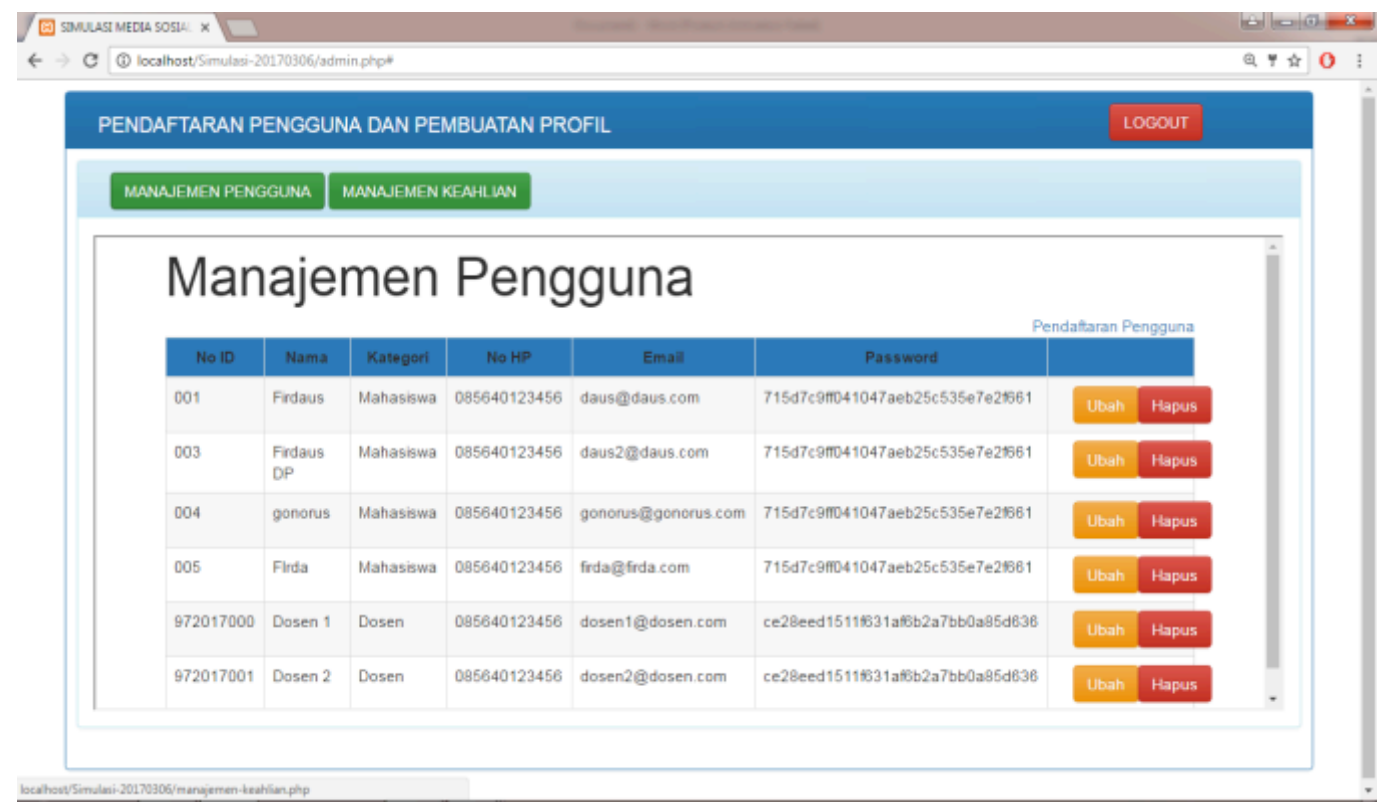

Gambar 3 Halaman Muka Admin

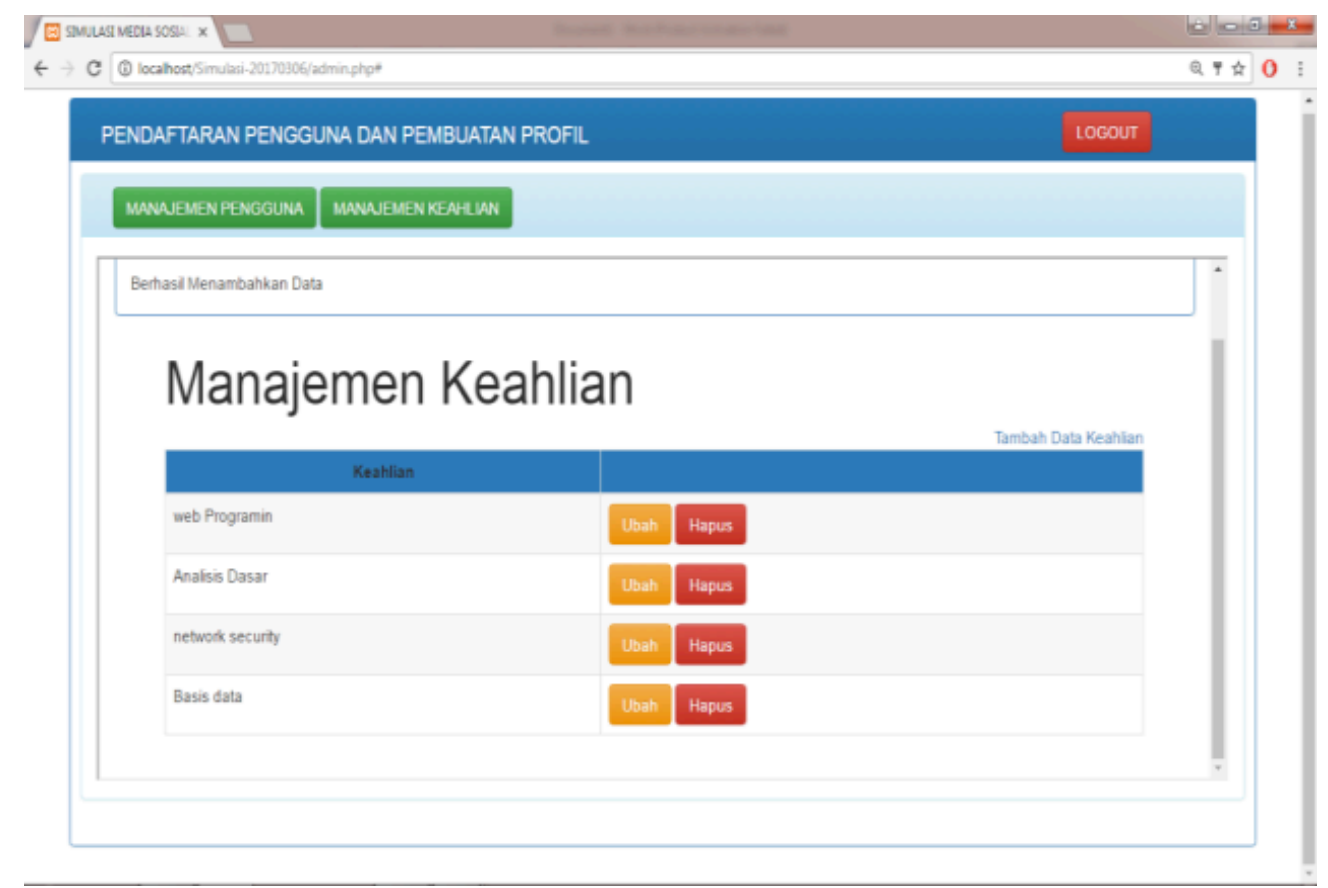

Gambar 4 Manajemen Pengetahuan

Aplikasi ini memiliki fitur chat yang ditujukan bagi pengguna. Fitur chat terdiri atas private chat untuk berhubungan satu ke satu pengguna dan group chat untuk berhubungan antar lebih dari satu pengguna, Fitur ini diharapkan dapat memberikan hubungan baik antar pengguna aplikasi di bidang pendidikan seperti pada gambar 5 . 


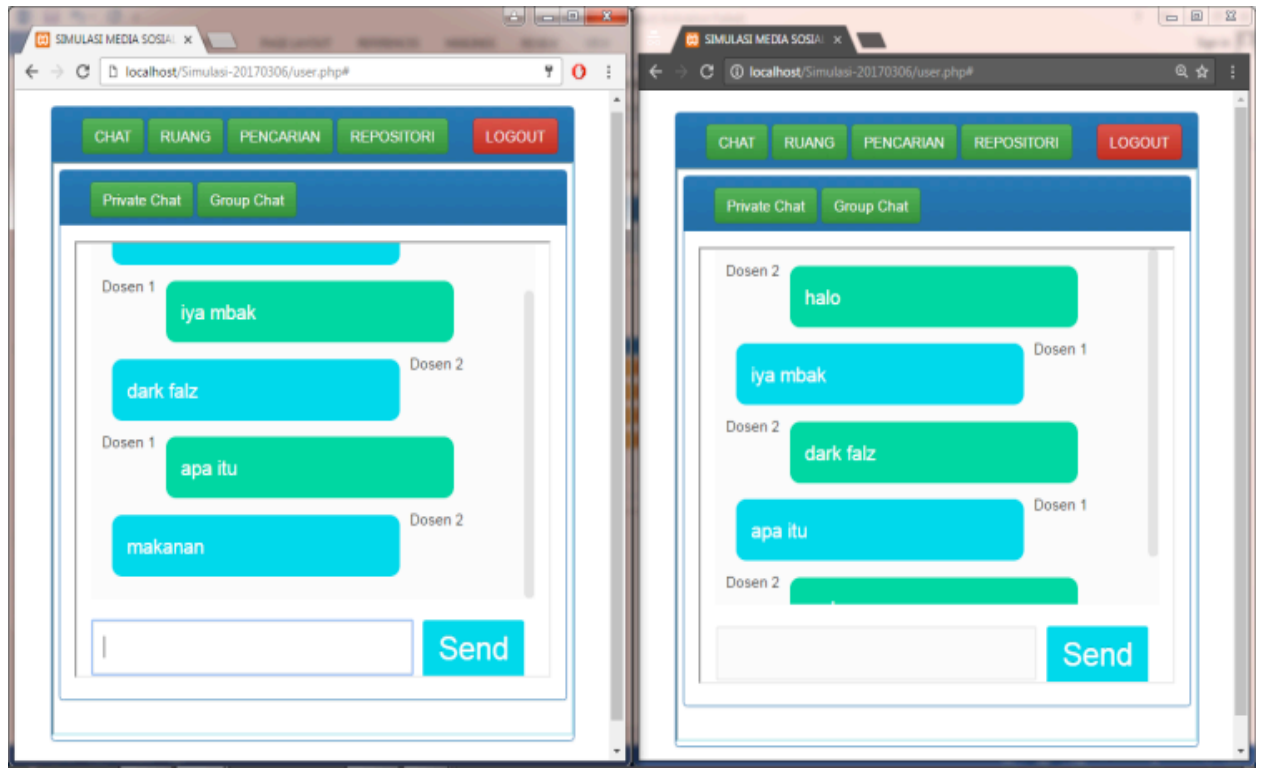

Gambar 5 Fitur Chat

Gambar 6 menjelaskan fitur ruang pada aplikasi. Fitur ruang merupakan tempat diskusi untuk materi dari dosen atau diskusi bebas (topik diluar materi yang diberikan). Pembuat ruang akan bertanggung jawab untuk semua masalah dalam ruang diskusi. Lecture merupakan narasumber dalam ruang diskusi untuk memberikan materi yang sesuai dengan topik yang ada pada judul ruang dan sebagai pemandu dalam ruangan. Gambar 7 menjelaskan tentang detail ruangan yang mencantumkan data pembuat ruang, lecture, anggota yang bergabung dan topik yang dibahas pada ruang pembelajaran.

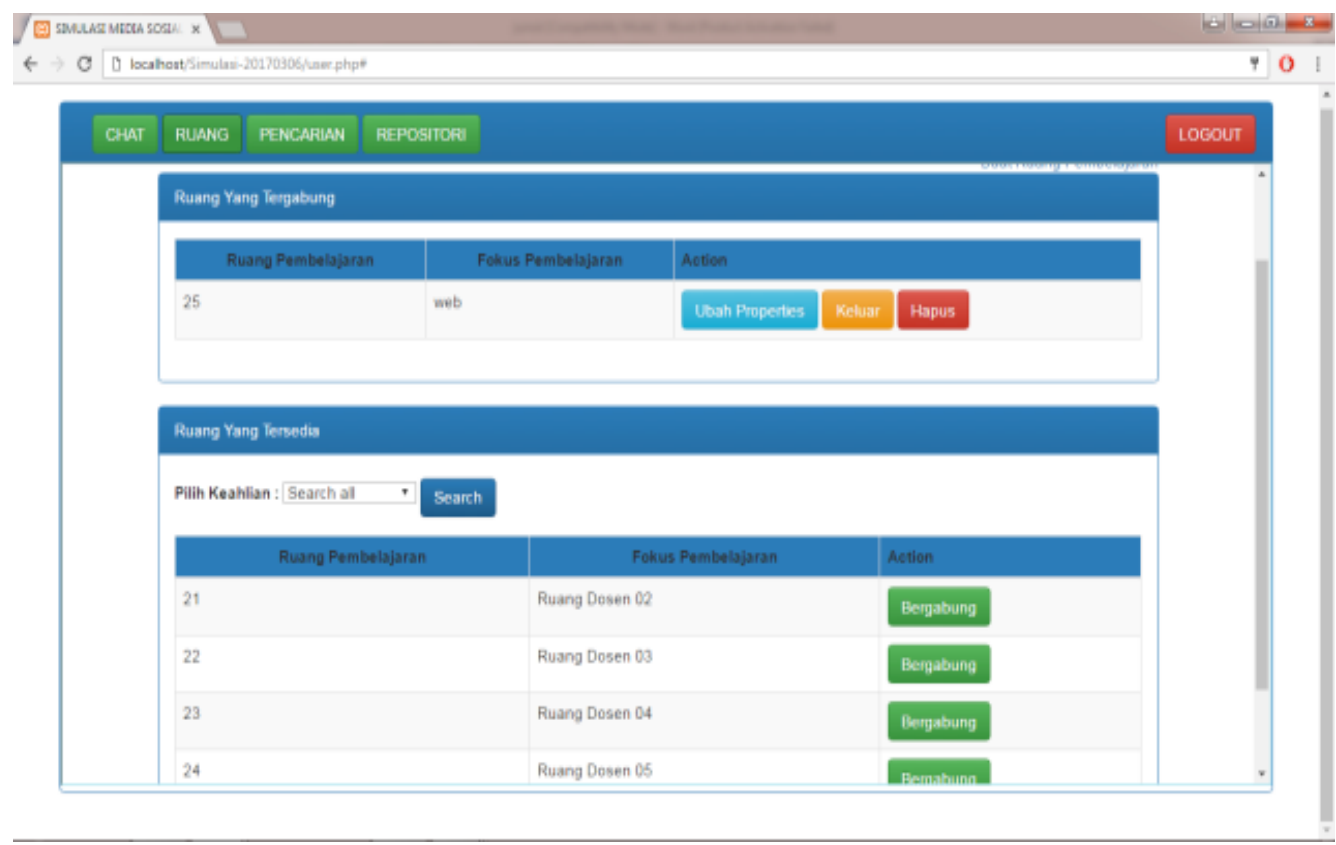

Gambar 6 Fitur Ruang Pembelajaran 
Computatio: Journal of Computer Science and Information Systems, volume 1, no 2, Oktober 2017

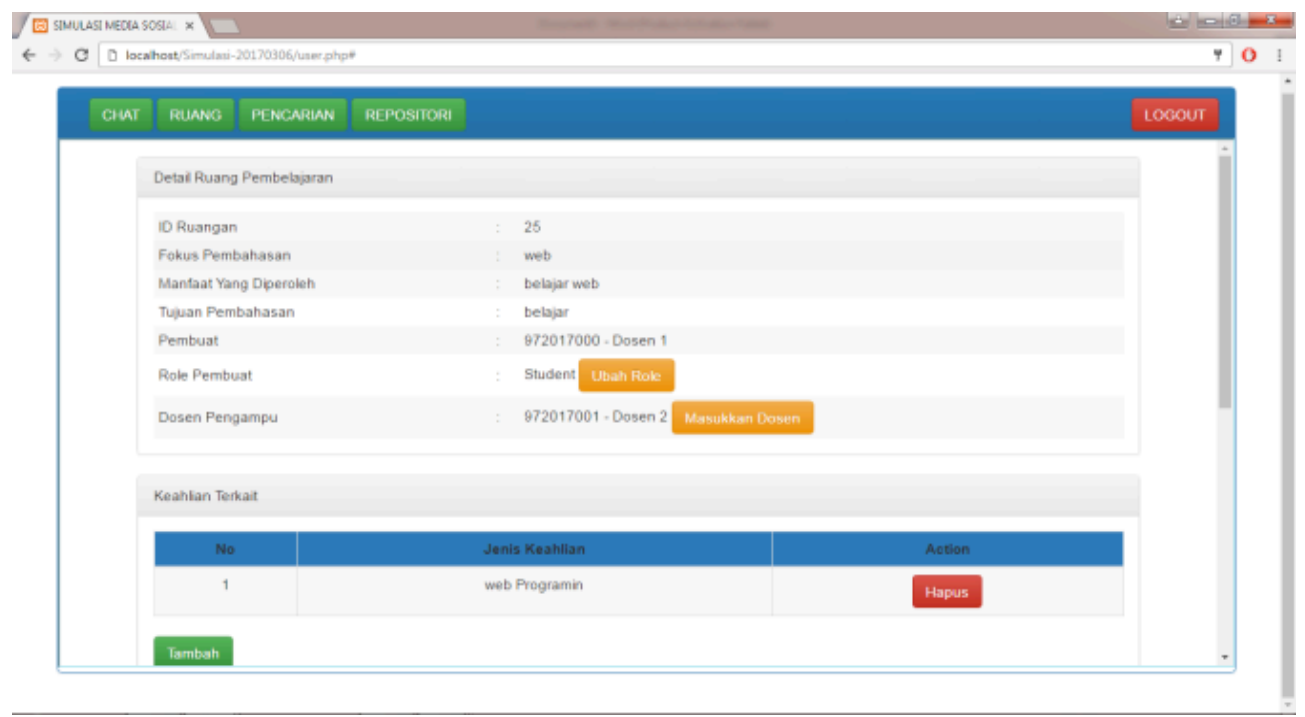

Gambar 7 Detail Ruang Pembelajaran

Simulasi ruang belajar dapat dilihat pada gambar 8. File yang ada pada simulasi diambil dari repository pada aplikasi. User akan saling memberikan pendapat tentang topik ruang belajar. Pembuat room bertangung jawab menghapus ruang dan menambahkan lecture untuk membantu pembelajaran dalam ruang diskusi.

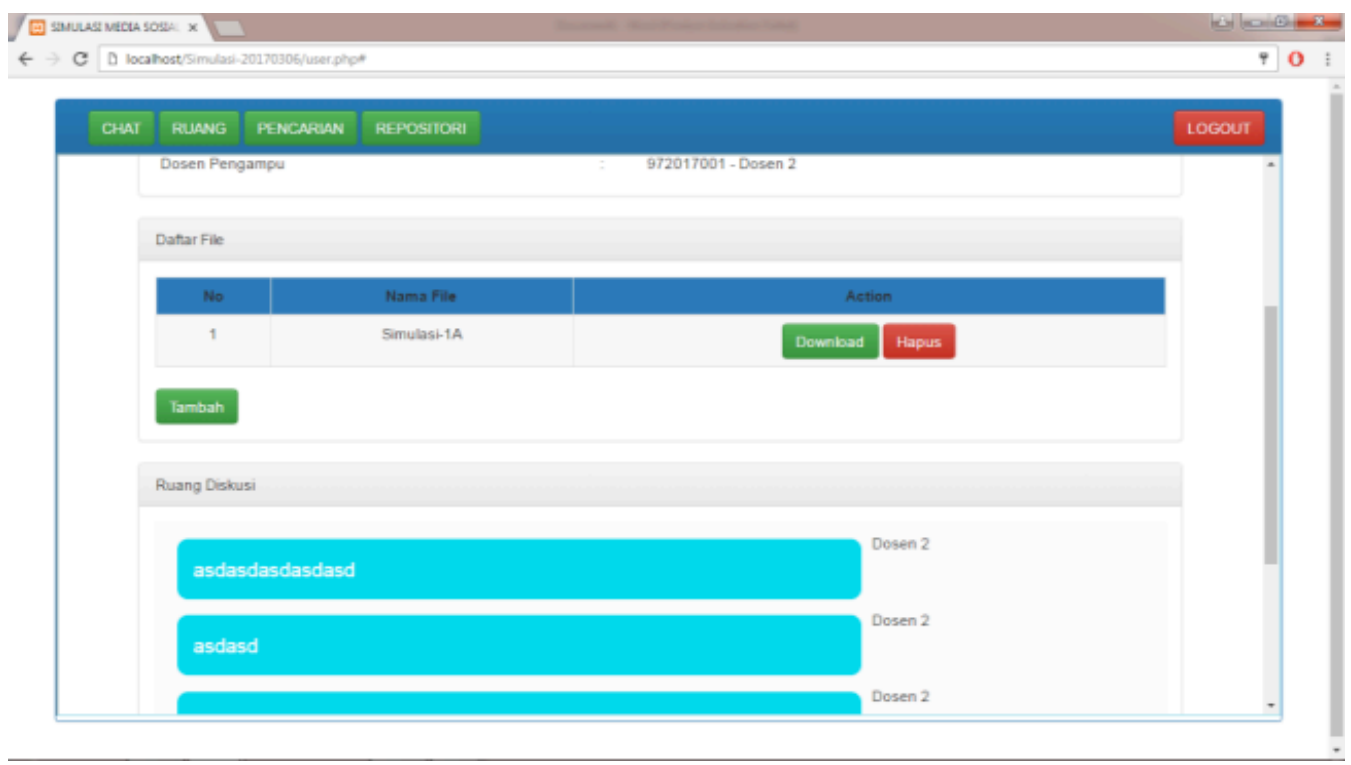

Gambar 8 Simulasi Ruang Belajar

Gambar 9 menunjukkan Fitur Pencarian. Fitur pencarian pada aplikasi dibagi menjadi pencarian user dan pencarian lecture. Proses pencarian lecture berdasarkan jenis keahlian yang dimiliki, semua lecture akan ditampilkan berdasarkan kategori jenis keahlian yang dicari. Pencarian user akan menampilkan berdasarkan nama. 


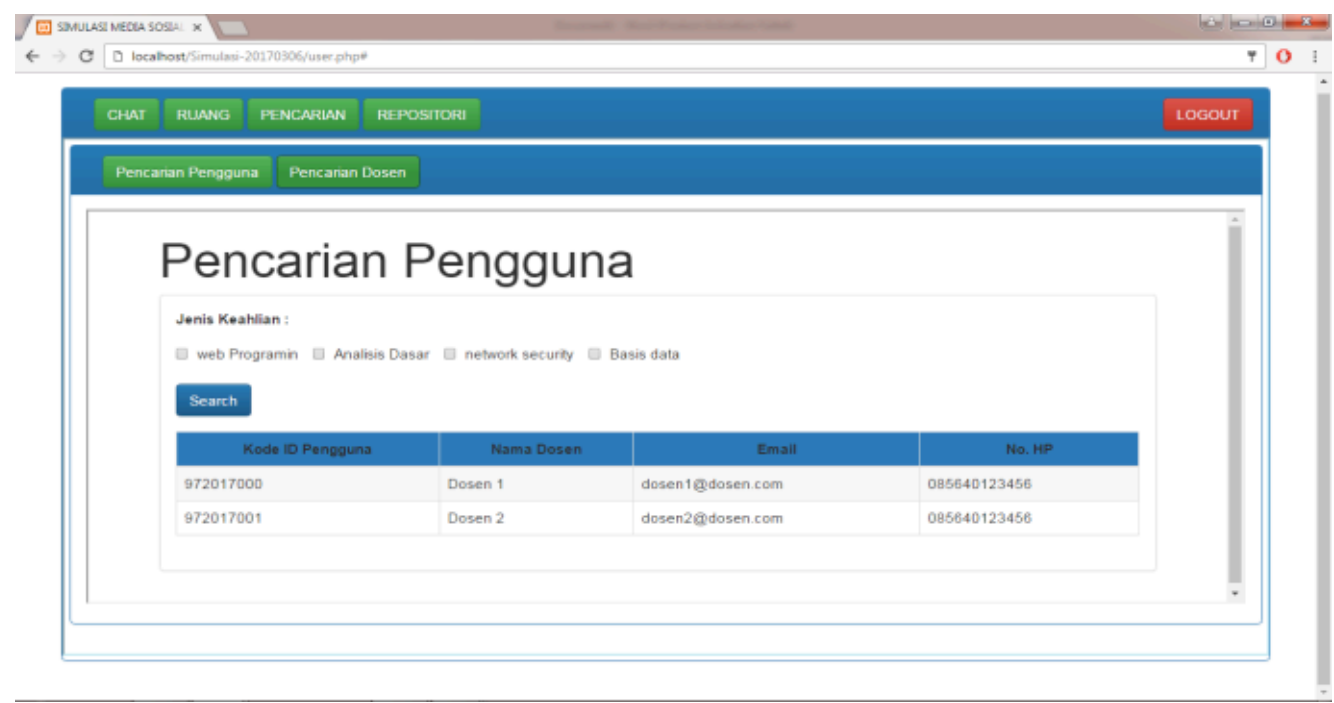

Gambar 9 Fitur Pencarian

Gambar 10 menunjukkan Repository. Repository merupakan tempat untuk upload dan download file materi, jurnal, whitepaper dan file yang berhubungan dengan pembelajaran atau diskusi. Semua user dapat melakukan upload file dengan kriteria yang sudah ditentukan.

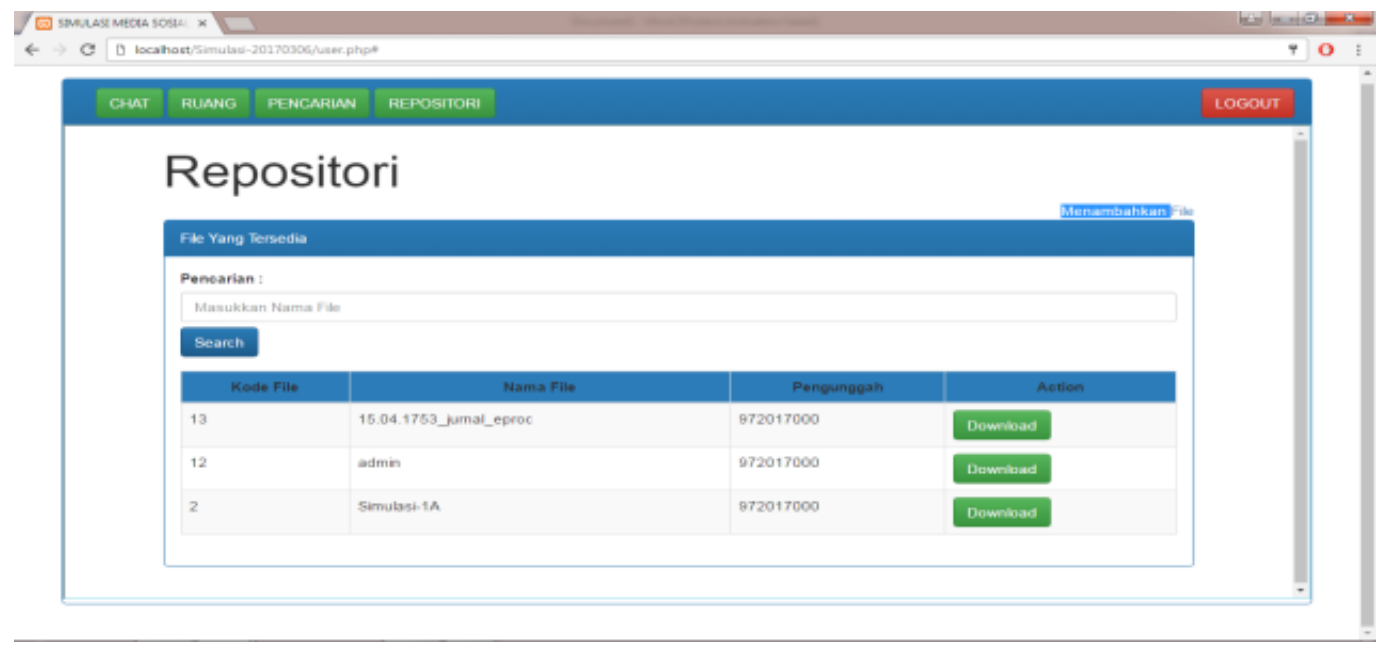

Gambar 10 Repositori

Penggolongan peran pada sistem aplikasi media sosial e-learning ini dibuat untuk membagi peran user media sosial. User dibagi perannya sesuai dengan bidang keahliannya masing-masing, misalnya sesorang user yang ahli dalam bidang hukum perdata, pada profil user pengguna tersebut akan ada sebuah simbol yang menerangkan bahwa dia ahli dalam bidang hukum perdata. Dengan demikian user tersebut dapat menjadi narasumber dalam ruang belajar dengan fokus pembelajaran hukum perdata dan user lain yang berkepentingan dengan fokus pembelajaran tersebut menjadi student dalam ruang belajar tersebut. 


\section{KESIMPULAN}

Kesimpulan dalam penelitian ini adalah :

1. Media sosial e-learning menyediakan ruang diskusi pembelajaran bagi pengguna yang sedang membutuhkan informasi, dimana di dalam ruang diskusi terdapat lecture yang memberikan referensi tentang kebutuhan referensi dari pengguna.

2. Media sosial ini menyediakan penggolongan peran pada aktor pengguna sesuai bidang yang dikuasai oleh pengguna, sehingga pengguna lain dapat memperoleh referensi dan informasi yang sesuai dengan bidang yang dibutuhkan.

3. Media sosial ini dapat bermanfaat untuk memberikan referensi, informasi dan pembelajaran yang sesuai dengan kebutuhan pengguna.

\section{UCAPAN TERIMA KASIH}

Penulis mengucapkan terima kasih yang sebesarnya-besarnya kepada Prof. Dr. Ir. Eko Sediyono, M.Kom, Dr. Anwar S. Ardjo yang telah memberi masukan terhadap penelitian ini.

\section{DAFTAR PUSTAKA}

[1] Setyani, Novia. Ika., 2013, Penggunaan Media Sosial sebagai Sarana Komunikasi bagi Komunitas (Studi Deskriptif Kualitatif Penggunaan Media Sosial Twitter, Facebook, dan Blog sebagai Sarana Komunikasi bagi Komunitas Akademi Berbagi Surakarta). Jurnal Komunikasi.

[2] Ependi, Usman., 2014, Implementasi Metode OOAD pada Perancangan Kamus Istilah Akuntansi Berbasis Mobile, Seminar Nasional Teknologi Informasi dan Komunikasi 2014 (SENTIKA 2014).

[3] Sugiarti, Yuni., 2013, Analisis \& Perancangan UML (Unified Modeling Language) Generated VB.6, Edisi Pertama, Graha Ilmu, Yogyakarta

[4] Yazdi, Mohammad., 2012, E-learning Sebagai Media Pembelajaran Interaktif Berbasis Teknologi Informasi, Jurnal Ilmiah Foristek, Vol. 2, No. 1, Maret 2012.

[5] Alkaff, Faizah., dkk. 2013, Analisis dan Perancangan Perangkat Lunak Media Sosial Untuk Berbagi Informasi Diskon. JURNAL TEKNIK POMITS Vol. 2, No. 2, (2013) 